\title{
The Impact of Free Primary Education Inputs On Educational Outcomes in Kenya (2003 To 2013): The Rate of Enrolment and Retention at Primary School Level as a Factor
}

\author{
Dorothy Akinyi Owuor, PhD \\ $\mathrm{PhD}$ Thesis, 2016, Moi University, Kenya \\ Supervisors: \\ Professor Laban, P, Ayiro ss \\ Department of Education Management and Policy Studies, \\ currently Ag. Vice Chancellor Moi University, Kenya \\ Professor Jackson Too \\ Department of Curriculum, Instruction and Educational Media, \\ Moi University, Kenya
}

Doi: 10.19044/ejes.v5no1a2 URL:http://dx.doi.org/10.19044/ejes.v5no1a2

\begin{abstract}
Free Primary Education Initiative has been running for more than a decade and its purpose has been to help Kenya achieve equity, parity, quality and higher retention rate in primary schools. This study investigated the impact of FPE inputs on educational outcomes in Kenya. The objective of the study was to determine the rates of enrolment and retention at Primary school level. Random sampling was used for data collection at school level; purposive sampling for teachers namely Head teachers, Deputy Head teachers and senior teachers. Out of a population frame of 641 schools and 7776 teachers from the ten Sub-Counties in Nakuru County, the sample comprised of 384 teachers from 128 primary Schools. Data was collected using questionnaires for teachers and Interview Schedules for the Quality Assurance and Standards Officers and Education officers. The study used both Descriptive and Inferential Statistics for analysis. The findings, therefore confirm an increased rate of enrolment and retention rate. The findings are intended to influence the Government to enhance provision of quality education. This study was also intended to make the government re-asses its education policy and budget allocation so that they target educational inputs that would have the greatest influence on learning outcomes.
\end{abstract}

Keywords: Enrolment, Retention, Inputs, Outcomes. 


\section{Introduction \\ Background}

Education has been considered a basic human right since 1948 with the universal Declaration of human rights and is meant to be accessible to all people. In pursuit of these goals, UNESCO organized a conference at Jomtien, Thailand in 1990 to discuss ways of achieving the goal of education for all and lifelong education. The delegates agreed that there was need to ensure all school age children were provided with an opportunity to enrol (GOK, 2006).

Heyneman (2007) on a study in Uganda posits that specific education inputs generally matter more in developing countries than in developed. Financial resources available to a school system are an input to the school and their availability is crucial in developing countries. Other factors that describe the resources that go into the school system include, teachers' qualifications and instructional materials, recruitment of teachers, an empowered school development Committee, curriculum implementation and in service of teach. This study considered instructional materials, infrastructure and remuneration (Paying support staff). Education outcomes mean how good pupils learn and the extent to which their education translates into a range of personal, social and development benefits.

The outcomes were expressed in a broader social and economic gains, enrolment and retention trends, dropout rates and transition to secondary schools, gender parity and quality UNESCO (2008). Sub-Saharan Africa's Gross Intake Rate (GIR), which registers the number of new entrants regardless of age, recorded the biggest increase in the world between 1999 and 2006 by $22 \%$ (UNESCO, 2009). Kenya is among the five African countries in Sub-Saharan Africa that has abolished Primary School tuition (offering FPE) to strengthen provision of quality education. In 2007 the gross enrolment rate rose to $112.4 \%$ and the net enrolment rate stood at $86.5 \%$ (UNESCO, 2007). The Enrolment in Primary Schools has increased from 5.9 million in 2003 to 8.6 million in 2009 .

\section{Research Problem}

Despite the massive funding on the part of the government to Education; 2011 (13.5\% of National budget); 2012 (23\% of National budget); 2013 (25\% of National budget); 2014 (27\% of National budget), critical educational indices of attainment such as enrolment, retention and performance remain a concern (KNBS, 2014). According to the World Bank report published in 2010, the school enrolment in primary in Kenya was $82.75 \%$ in 2009 .It has not been steady as in 2006 it was $86.27 \%$ but declined in Jan 2008 to 82.78 . According to an Institute of Statistics study carried out between 1970 to 2009 gross enrolments declined between 2005 and 2006 as it 
increased from $106.90 \%$ to $107.05 \%$ only to decline in 2006 to 105.58 . (UNESCO 2010).

The above statistics indicate that if nothing is done, the attainment of EFA and vision 2030 will remain elusive despite the massive infusion of funds through the FPE initiatives.

\section{Purpose for the Study}

The purpose of this study was to assess the impact of FPE inputs on educational outcomes in Kenya namely, enrolment and retention at primary level between 2003 to 2013 .

\section{Objective of the Study}

To determine the Rate of Enrolment and Retention at Primary School Level.

\section{Theoretical Framework}

The study was based on the Education Production Function Theory to estimate determinants of learning outcomes. A production function specifies the output of a firm, an industry, or an entire economy for all combinations of inputs (Hanushek, 2007). Although schools are not profit- maximizing firms, the framework treats them as production units on the supply side. Production function studies have been used extensively to identify factors that "produce" good learning outcomes. 


\section{Conceptual Framework}

Figure 1: The implications of FPE inputs on educational outcomes.

Dependent variables

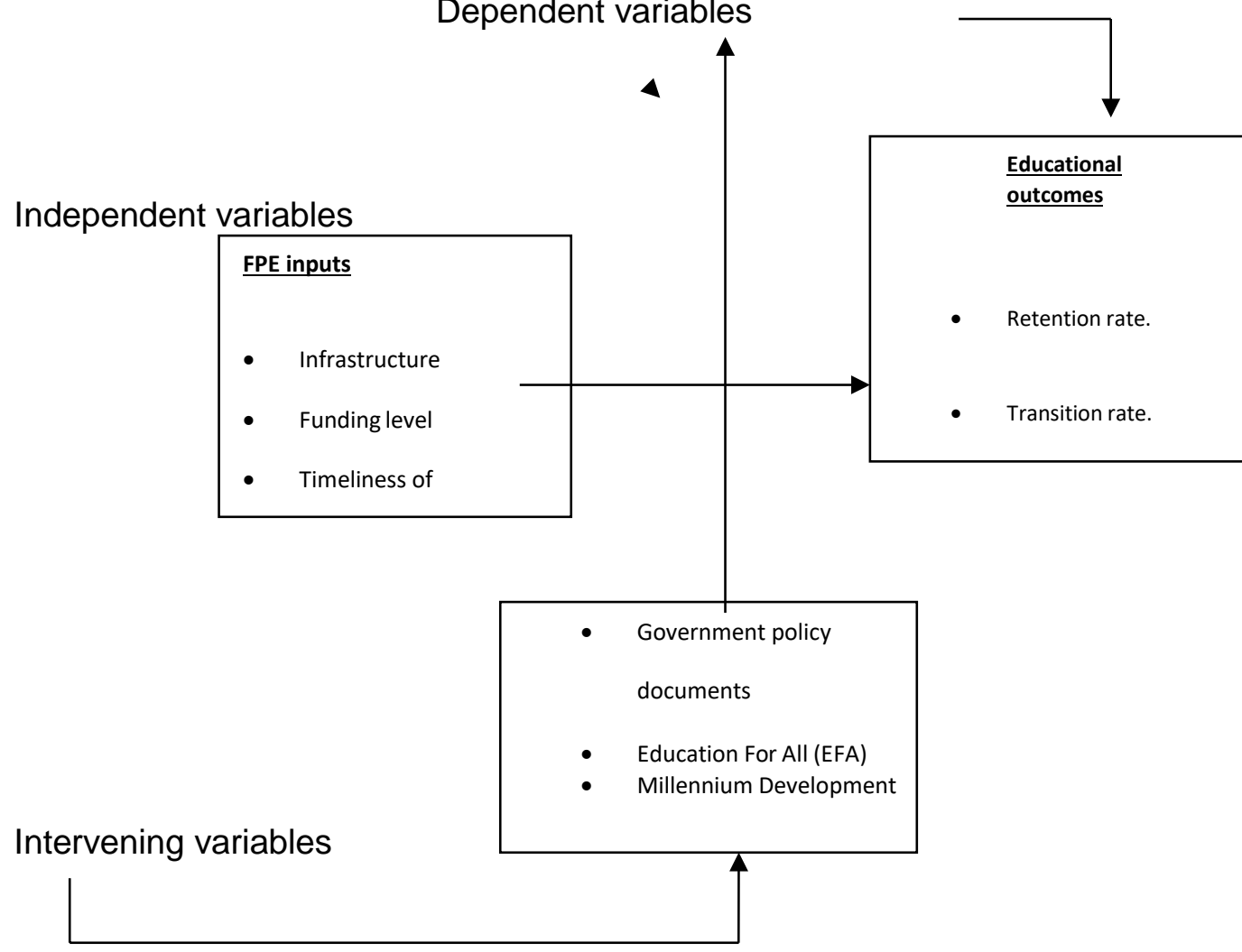

Since education is important in National Development, the government must find out what can be done to improve learning in public primary schools. The study consisted of the relationship between funding and disbursement, school accountability and instructional materials, were considered as the Independent Variables likely to affect Educational outcomes in this case.

Retention and Enrolments rate. It is only through the educational outcomes that the country will achieve the objectives of Sessional Paper No.14 of 2012, Vision 2030, MDGs and finally EFA goals.

Figure 1 shows the conceptual model, which encompasses the major variables and their patterns of influence on each other and eventually on Educational outcomes in public schools. Due to FPE inputs more students joined school and while 85 percent of primary school-aged children are enrolled in school worldwide, these higher levels of enrolment may not be translated into increased learning for students in Kenya, as the quality of education is questionable. This may be due to in part, to lack of proper school materials, which are often under supplied to poorer or more remote areas. 
There is a widespread belief that the provision of school materials can substantially improve educational outcomes in rural, underdeveloped areas, however there is little empirical evidence to confirm this.

\section{Literature Review}

The Independent variable here is FPE inputs while the dependent is Educational outcomes. The themes under which the following literature is reviewed are: the rationale for education for all (EFA), FPE inputs in developed and developing countries, FPE Inputs in Sub-Saharan Africa, on inputs in Kenya and FPE Inputs versus Educational outcomes in Kenya.

\section{The Rationale for Education for All (EFA)}

The six EFA goals include major reforms in the Education Sector (GOK, 2007) were:

i)Expanding and improving comprehensive early childhood care and education, especially for the most vulnerable and disadvantaged children ii) Ensuring that by 2015 all children particularly girls, children in difficult circumstances and those belonging to ethnic minorities, have access to and complete, free and compulsory Primary Education of good quality iii) Ensuring that the learning needs of all young people and adults are met through equitable access to appropriate learning and life skills programs iv) Achieving a 50\% improvement in levels of Adult Literacy by 2015, especially for women, and equitable access to basic and continuing education for all adults v) Eliminating gender disparities in Primary and Secondary Education by 2005 and achieving gender quality in education by 2015, with a focus of ensuring girls full and equal access to and achievement in basic education of good quality and vi) Improving all aspects of the Quality of Education and ensuring excellence of all so that recognized and measurable learning outcomes are achieved by all, especially in literacy, numeracy and essential life skills.

Education for All Development Index measures the extent to which countries are meeting four of the six EFA goals which are: UPE, gender parity, literacy and quality. Several countries - including some of the poorest sharply improved their EFA achievement levels between 1998 and 2001. This indicates that poverty is not a barrier to rapid progress towards EFA. On the other hand, low standards of education characterize Sub-Saharan Africa, the Arab States and South and West Asia.

\section{Educational Outcomes}

Educational outcomes are broadly conceived as literacy, numeracy and life skills, creative and emotional skills, values and the social benefits of education. Whilst the quality of education depends on learner characteristics and system inputs, the implication is that quality is evidenced by outcomes. 
Knowledge and cognitive skills because they are relatively value-neutral compared to other educational goals and hence more amenable to measurement through standardized testing (UNESCO, 2002). The five dimensions of the UNICEF framework are defined as (i) what learners bring to learning; (ii) learning environments; (iii) content; (iv) processes (v) outcomes.

\section{Educational Inputs and Outcomes in Developed Countries}

Hanushek (2007), in his recent review of production function studies in the United States showed average spending to have risen over time while test scores remained flat, a problem he attributes to the weak effect of school inputs. His subsequent review in developing countries reached essentially the same conclusion. He found the traditional approach to improving student outcomes - increasing inputs - to be an ineffective policy option, given that no systematic relationship can be found between inputs in the aggregate and test scores.

\section{FPE Inputs in Sub- Saharan Africa}

While the Sub-Saharan governments continues to receive credit due to increase in enrolment and availability of textbooks in schools, (with pupil textbook ratio 2:1 in some schools) the Education for All Global monitoring reports indicate that the quality of education remains poor in most SubSaharan countries including Kenya. Nigeria has implemented Free Primary Education on and off since the 1950s and 2003, with literacy level still at 55 $\%$ (Aj etombi \& Ayanwale, 2005). Figures from UNESCO's 2010 Education for All Global Monitoring Report shows that the region's children are still missing out. According to Ondego (2008), from the more than 1.5 million who enrolled, only about 500,000 sat Kenya Certificate of Primary Education examination. The challenge is not just enrolment but also maintaining the enrolled children in school. However, Wasanga, Ambia and Mwai (2010), say that at Primary school level, there is no systematic monitoring of who drops out and why.

\section{FPE Inputs vs. Educational Outcomes in Kenya}

Following the NARC government initiative, the number of primary school pupils all over Kenya increased by $18 \%$ from 6.06 million pupils in 2002 to 7.16 million pupils in 2003 a remarkable increase as rates of annual increase before the FPE initiative had been less than $1 \%$ (Government of Kenya 2004) enrolment continued to rise phenomenally from 5.9 million in 2002 to 8 million in 2007. Ogola (2010) on challenges of FPE, observed that there are mixed ages in the schools with some having overage pupils. In his 
interview with teachers, he emerged that there were pupils with thirteen years in class two and twenty years in class eight.

In a speech delivered at the 34th UNESCO general conference in 2007, Kenya's minister for education indicated that the gross enrolment rate was $112.4 \%$ and the net enrolment rate stood at 86.5..With classrooms originally meant for 40 children now accommodating up to 80 children (such as in Nairobi slums), there is a real concern that this will impact negatively on the quality of teaching and learning This is echoed by Wax (2003) who writes that some Kenyan students had not even been able to formally meet their teacher, with a line forming after class each day just to shake the teacher's hand.

In the past decade all three governments (Kenya, Uganda and Tanzania) in the region have increased spending by up to threefold, and now allocate upwards of $6 \%$ of their GDP to the education sector .According to SACMEQ III(2011) Primary schools in Kenya can also access government funding for construction and improvement of facilities through the Constituency Development Fund (CDF) A reason these investments are not yielding better results may be explained by their being spent on aspects that are not the biggest drivers of learning. The bulk of government expenditure goes toward construction and teachers' salaries, but there is little evidence to show that these measures are strongly linked to improved learning

\section{Research Methodology}

This study adopted a pragmatic world view in its philosophical paradigm to investigate the Impact of FPE Inputs on Educational Outcomes at Primary Schools in Kenya. This pragmatic option allows for a mixed methods approach to the design of the study, engaging both qualitative and quantitative methods. Pragmatism as a worldview arises out of actions, situations, and consequences rather than antecedent conditions. There is concern with applications -what works- and solutions to problems (Patton, 1990).It is more than simply collecting and analysing both kinds of data; it also involves the use of both approaches in tandem so that the overall strength of a study is greater than either qualitative or quantitative research (Creswell, 2009).

The population of the study involved Public Primary Schools since there has been FPE input in all the public primary schools. It involved Head teachers, Deputy Head teachers, senior teachers, Sub- County Quality Assurance and Standards Officers and Sub-County Education Officers, since they are directly involved in the implementation and evaluation of Free Primary Education.

The sample and sampling procedure of the study involved 641 schools with a population of 7776 teachers. According to Krejcie \&Morgan (1970) table this gave a sample size of 366 statistically. 366 were distributed proportionately based on the simple ratio of the number of schools per sub- 
county. This distribution gained 18 questionnaires for Nakuru East, Nakuru West-18, Njoro-46, Naivasha-40, Gilgil-34, Nakuru North-20, Molo-28, Rongai-40, Subukia-22, Kuresoi-98. This added up to 366 . However, only 360 were returned by the respondents. A random sampling was done in order to get the schools where questionnaires were to be administered to the Head teacher, Deputy Head teacher and senior teacher. In each school therefore 3 questionnaires were administered. The study also involved 3 Quality Assurance and Standards Officers and 3 Sub- County Education Officers. The Quality Assurance and Standards Officers were from Subukia, Nakuru North and Nakuru with average populations while the Sub- County Education Officers were from Kuresoi, Naivasha and Nakuru (East and West).

The research used two instruments for the study that is, questionnaires and interview guide. Cronbach's Alpha was used to test the reliability of the instrument. In this case the researcher tested the reliability in Baringo County where piloting was done to test scores obtained by each respondent over the first and second test. The questionnaires were piloted with a small representative sample population (15 respondents) identical to, but not included in the final sample group in the study.

The data collected was subjected to mixed method analysis approach. The sample size of the study was 360 subjects, which can allow the generalization of the study. Descriptive statistics like, mean, mode, frequencies, percentages, tables, and charts were used. Data was collected by means of both questionnaires and interview schedules. Questionnaires were the major instrument as all the Head teachers, Deputy head teachers and Senior teachers totalling 360 used it while only 3 Sub-county Quality Assurance and Standards Officers and $3 \mathrm{Sub}$-County Directors of Education were subjected to Interview Schedules.

\section{Findings/Results}

\section{Rate of enrolment and retention at primary school level}

The constructs needed to measure the rate of enrolment and retention were: class sizes, Teacher: Pupil ratio, pupil participation, dropout ratio, retention ratio, multishift, classroom construction, transition rate and gender parity.

\section{1ncrease in Class Sizes since Inception of FPE}

Out of the 360 respondents who were asked to comment on the increase in class sizes, the response rate was $96.7 \%$ 
Table 1: Increase in Class Sizes since Inception of FPE

\begin{tabular}{lll}
\hline Responses & Frequency & Percent \\
\hline No increase & 8 & 2.2 \\
Minimal & 8 & 2.2 \\
Increase High & 101 & 28.1 \\
increase Total & 231 & 64.2 \\
& 348 & 96.7 \\
\hline
\end{tabular}

Respondents were asked to state if their schools had seen increases in class size as shown in Table 1 and $92.3 \%$ said they had seen increases in class size while $4.5 \%$ thought otherwise. This statistic is in line with the figures in GOK (2007) that revealed an influx of 1.5 million children in school at the inception of FPE. It mirrors the situation in Sub- Saharan Africa by UNESCO (2010) where enrolments are generally on the rise. Over enrolment influences the quality of education. It triggers a chain reaction touching on teacher and facility adequacy, teaching method, sitting arrangement, working space, examination and assessment, sanitation among other things. The present primary school teacher is trained to handle an average of forty pupils per class.

\section{Pupil: Teacher: Pupil Ratios}

In this study $95.8 \%$ of the respondents made comments on whether teacher: pupil ratios were acceptable.

Table 2 Teacher: Pupil Ratios

\begin{tabular}{lll}
\hline Responses & Frequency & Percent \\
\hline Very inappropriate Not & 99 & 27.5 \\
appropriate Appropriate & 166 & 46.1 \\
Very appropriate Total & 68 & 18.9 \\
& 12 & 3.3 \\
& 345 & 95.8 \\
\hline
\end{tabular}

When asked whether the pupil: teacher ratios were acceptable, most respondents said they were not appropriate. This is confirmed by the TSC Annual Report-2009 which shows the total number of teachers on duty verses the curriculum based established (CBE), and the shortage in various public primary schools. The report further amplifies the deficiency in teacher numbers in view of the establishment of an additional 8000 new primary schools since the introduction of FPE.A much larger teacher workforce is needed to respond to the burgeoning class size, this demand is rarely met. UNESCO (2005), in its nationally representative study of the implementation of FPE in Kenya revealed that the average school visited was short of two to three teachers. This agrees with the findings in this study. 


\section{Individual Attention from Teachers to Pupils}

Respondents were asked if pupils get individual attention from their teachers and 96.4 responded.

Table 3 Individual Attention from Teachers to Pupils

\begin{tabular}{lll}
\hline Response & Frequency & Percent \\
\hline No attention Minimal & 72 & 20.0 \\
attention Due attention & 163 & 45.3 \\
All the attention & 99 & 27.5 \\
Total & 13 & 3.6 \\
& 347 & 96.4 \\
\hline
\end{tabular}

On whether pupils were getting individual attention from their teachers, it came out clearly from $45.3 \%$ of the respondents that they got minimal attention while $31.1 \%$ said that they got enough attention. This implies that high enrolment amidst diminished teacher numbers affects the interaction levels between the teacher and the pupil negatively. Slow learners then become disadvantaged. An increased pupil population poses serious challenges to classrooms interactions resulting in high demand for teachers in the 18,000 plus primary schools in the country (GOK, 2004). Teacher shortages has led to a high teacher: pupil ratio; in some schools that ratio is $1: 70,1: 80$ or even 1:100; this exceeds the recommended maximum rate of one teacher to 40 learners, that is 1:40. This makes it difficult for teachers to pay attention to all learners, give adequate assignments to the pupils or even to inculcate discipline among their pupils.

Large class size also leads to teachers' inability to provide attention to individual pupils. Wax (2003) writes that some Kenyan students had not even been able to formally meet their teacher, with a line forming after class each day just to shake the teacher's hand. Within the classroom, teachers had to yell to be heard and some even used megaphones to teach the large number of pupils. Teachers have also resorted to less participatory approaches to learning.

There is, however, some indication that teachers have developed creative ways to cope with their overflowing classes. In Malawi, as observed by Croft (2002), effective teachers had adapted their curriculum by using songs to teach specific subject material. Teachers used songs to keep children occupied while they wrote on the board, to call children to the start of class, and to signal a change in subject or activity.

\section{Pupils Participation}

Out of the 360 respondents who were asked whether pupils got opportunities to participate, $95.6 \%$ gave various answers 
Table 4: Pupils Participation

\begin{tabular}{lll}
\hline Responses & Frequency & Percent \\
\hline No attention & 10 & 2.8 \\
Not sure & 68 & 18.9 \\
Sometimes & 236 & 65.6 \\
Always Total & 30 & 8.3 \\
& 344 & 95.6 \\
\hline
\end{tabular}

The respondents were asked to indicate the level of participation by the pupils in class. In Table 4, $21.7 \%$ believed pupils did not get the opportunity to participate while $73.9 \%$ said at times they got. The data analysed shows that despite the high enrolment rate, pupils still got a chance to take part in class activities. Despite the lack of individual attention given to pupils there is a consensus that they participated. That there is not enough interaction between a teacher and the learner is impacting negatively on the quality of education in public primary schools.

\section{Dropout Rate}

Respondents were asked if the dropout rate has gone down since the inception of FPE and the response rate was $96.1 \%$.

Table 5: Dropout Rate

\begin{tabular}{lll}
\hline Responses & Frequency & Percent \\
\hline Increased Slightly & 17 & 4.7 \\
increased Decreased & 60 & 16.7 \\
Slightly decreased Total & 194 & 53.9 \\
& 75 & 20.8 \\
& 346 & 96.1 \\
\hline
\end{tabular}

On dropout rate $21.4 \%$ of the respondents felt that it is has increased while $74.7 \%$ opined that since the inception of FPE, many pupils have remained in school as shown in Table 5. The dropout rate could have decreased as there are no user charges that previously made pupils to be sent away from school. Elimu Yetu (2004), confirms that teachers were of the view that FPE has positively impacted on the dropout rates. Unfortunately, there were no records indicating whether those who dropped out went to other schools. According to Wasanga, Ambia and Mwai (2010), at Primary school level, there is no systematic monitoring of who drops out and why. However, figures from UNESCO's 2010 Education for All Global Monitoring Report for Sub-Saharan Africa shows that while enrolment rates are rising, millions of children enter primary school only to dropout before completing a full primary cycle. Some 28 million pupils in Sub-Saharan Africa dropout every year. This contradicts the study's findings and it presupposes that as developing countries grapple with the challenges of rapidly expanding their education system, dropout rates are high and literacy and numeracy levels 
remain low as stated by UNESCO (2010). This is further confirmed by KNEC (2014) which states that more than a third of pupils who joined standard one in 2007 did not complete their studies. While releasing KCPE results for 2014, Education Cabinet Secretary Professor Kaimenyi said that out of 1,312,206 pupils who were enrolled in standard one in 2007, only 880,486 sat for KCPE examinations that year.

The dropout rate in public primary schools is also very alarming. A clear indication of this is the difference between the number of pupils who joined primary school in Class One in 2003 and those who completed the eight-year cycle in 2010; from the more than 1.5 million who enrolled, only about 500,000 sat Kenya Certificate of Primary Education examination according to Ondego (2008). This begs the question, there other factors that affect school attendance apart from school fees.

\section{Retention Rate}

The study had $95 \%$ of the respondents giving comment on whether the retention rates in their schools had improved.

Table 6: Retention Rate

\begin{tabular}{lll}
\hline Response & Frequency & Percent \\
\hline Very low & 13 & 3.6 \\
Low High & 51 & 14.2 \\
Very high & 239 & 66.4 \\
Total & 41 & 11.4 \\
& 344 & 95.6 \\
\hline
\end{tabular}

The findings in Table 6 reveal that $27.8 \%$ of the respondents saw retention rates as still low while $77.8 \%$ affirmed that the retention rate had generally increased. This indicates that FPE has made children complete primary education due to the absence of extra levies. This conflicts with the UNESCO (2010) findings, which showed that despite the increased enrolment arising out of FPE, several factors have made it difficult to maintain the figures. It is evident that the focus need not be on just enrolment but on maintaining the enrolled child in school. The Shanghai poverty conference which did a case study in Kenya, Lesotho, Malawi, and Uganda on Free Primary Education (FPE) also did not share this sentiment. One of its outcomes was that high dropout and poor completion rates need to be addressed, and improving quality throughout remains a major challenge.

\section{Multishift}

The respondents who gave their opinions on whether multishift would improve the pupil's participation in class were $95.3 \%$. 
Table 7: Multishift

\begin{tabular}{lll}
\hline Responses & Frequency & Percent \\
\hline Not significant Not & 72 & 20.0 \\
at all Significant & 134 & 37.2 \\
Very significant & 109 & 30.3 \\
Total & 28 & 7.8 \\
& 343 & 95.3 \\
\hline
\end{tabular}

On Multishift, $57.2 \%$ seemed to see this approach as insignificant to improved participation in class as shown in Table 7. This system would allow for partial attendance of pupils in school based on morning and afternoon shifts. This would alleviate the immense overcrowding witnessed in schools with some learners being taught under trees. One of the challenges alluded to earlier, and currently being experienced in schools, is overcrowding of classrooms especially in the densely populated areas which have led to very high pupil teacher ratios in some cases going up to a PTR of 1:100. To ensure that quality is enhanced in such schools the Government has introduced double shift with a view to maximising utilisation of space (GOK, 2004). This approach to learning has had many negative connotations as being inferior to the conventional whole day learning. However, the question of who teaches the multi shift lessons or extra classes remains a serious challenge. (Ogola, 2010)

\section{After School Tutoring Services}

The respondents who commented on whether there were after school tutoring services in their schools were $95 \%$.

Table 8: After School Tutoring Services

\begin{tabular}{llll}
\hline Responses & & Frequency & Percent \\
\hline & Not evident at all & 87 & 24.2 \\
& Not evident & 132 & 36.7 \\
Evident & 103 & 28.6 \\
Very evident & 20 & 5.6 \\
Total & 342 & 95.0 \\
\hline
\end{tabular}

The study also analysed the presence of after school tutoring and most of the respondents said that it was not evident in the schools anymore. There is a possibility that with the high enrolments the teachers are overworked and are not able to give extra lessons after school hours due to exhaustion. The essence of motivation is supposed to enhance commitment from the teachers an aspect that is diminishing due to the government policy over the issue. Majority prefer to teach where they can get an extra coin, a fact that is captured by a journal of Pan African studies and regardless of the explanation, the fact that the child's schoolteacher is very often the one providing the tutoring 
creates a potential distortion in teacher incentives. Anecdotal evidence suggests that teachers sometimes refrain from teaching some of the curriculum during school to generate demand for their fee-generating tutoring classes. Some parents have even opted to take their children to private schools where there is extra tuition. This comes with a fee which is paid by the parents.

\section{Construction of More Classrooms}

All the 360 respondents gave their views on the building of more classrooms in them Schools after 2003and $96.1 \%$ gave comment

Out of the $96.1 \%$ of the respondents, $44.7 \%$ disputed the construction of classes, while $51.1 \%$ confirmed the construction of classes after 2003 as shown in Table 4.12. The study shows that in some areas, classes were built while in other places classes were not built therefore we cannot attribute classroom infrastructure to FPE. These findings show that lack of classrooms is common place and align itself to SACMEQ III (2011) which revealed that Kenyan schools are lacking about a third of classrooms and the same number of sanitary units hence instead of head teachers concentrating on implementation of the school curriculum, they spend most of the time dealing

Table 9: Construction of More Classrooms

\begin{tabular}{llll}
\hline Responses & & Frequency & Percent \\
\hline & strongly disagree & 68 & 18.9 \\
& Disagree & 93 & 25.8 \\
& Agree & 143 & 39.7 \\
strongly agree & 41 & 11.4 \\
& & \\
Total & 346 & 96.1 \\
\hline
\end{tabular}

with congestion issues. Lack of adequate classrooms implies lack of adequate chairs and desks; this problem is compounded by tear and wear of the same

\section{Maintenance of Facilities/Services}

In the study $95.0 \%$ responded to the question on whether facilities / services have been maintained in their schools

Table 10: Maintenance of Facilities/Services

\begin{tabular}{clll}
\hline Responses & & Frequency & Percent \\
\hline Very low & 27 & 7.5 \\
Low & 78 & 21.7 \\
High & 203 & 56.4 \\
Very High & 34 & 9.4 \\
Total & 342 & 95.0 \\
\end{tabular}


In Table 10, 29.2\% of the respondents believed maintenance of the facilities is poor while $65.8 \%$ felt they have been well maintained. The government issued a directive that FPE does not require parents and communities to build new schools but instead encourage communities to improve, refurbish and use existing facilities (MOE, 2004). However, it is the responsibility of the government to improve existing school facilities, the building of new classrooms and new primary schools through the School Infrastructure Improvement Program (SIIP), which gives priority to schools serving communities in low rainfall areas and urban slums. This is however a task that is hard to accomplish considering the current budgetary allocation in Education .In an effort to maintain the existing facilities, there is an additional funding from the Constituency Development Fund (CDF), a kitty that is managed by the area Member of Parliament SACMEQ III (2011).However, it is notable that in Kenya today, approximately $50 \%$ of all the country's primary schools are housed in temporary and/or semi-permanent buildings; others are on split sites (Ngaroga, 1996). The declaration of free primary education witnessed the rise in student enrolment which in turn led to strain in the existing physical resources.

\section{Transition Rate}

On transition rate $95 \%$ of the respondents gave comments as shown in Table 11.

Table 11: Transition Rate

\begin{tabular}{lll}
\hline Responses & Frequency & Percent \\
\hline Average & 5 & 1.4 \\
Minimal & 40 & 11.1 \\
Greatly Very & 223 & 61.9 \\
greatly Total & 74 & 20.6 \\
& 342 & 95.0 \\
\hline
\end{tabular}

In Table 11, 12.5\% of the respondents said that the transition rate has been minimal while $82 \%$ said it has greatly improved. This could be because the pupils stay in school and complete the primary cycle as there are no levies charged. They are also joined by those who had previously dropped out and those who are over age (Ogola, 2010). However, the 2012 Economic Survey shows that approximately 30 per cent of primary school pupils fail to transit to secondary schools because secondary schooling is yet to be actualized. Its implementation would mean automatic progression. This affects transition. About 250,000 Kenya Certificate of Primary Education (KCPE) exam candidates miss secondary school slots annually. Whereas the Kenya Vision 2030 is looking upon the education sector to deliver the necessary skills and build adequate human capital to achieve and sustain the country as a middle- 
income country, such dismal transition rates are a major cause of concern in the education sector.

\section{Gender Parity}

On whether there has been gender parity on enrolment, $95.3 \%$ of the respondents gave comments

Table 12: Gender Parity

\begin{tabular}{lll} 
Responses & Frequency & Percent \\
\hline Not attained at all & 10 & 2.8 \\
Minimal & 55 & 15.3 \\
Relative & 227 & 63.1 \\
Attained & 50 & 13.9 \\
Total & 343 & 95.3 \\
& \\
\hline
\end{tabular}

On enrolment according to gender, $18.1 \%$ of the respondents believed gender parity has not been attained but $77 \%$ concurred that enrolment by gender was at par as shown in Table 12. This could be since girls are no longer left at home to do the house chores as boys are given priority to go to school. Factors such as girl child empowerment and their education have contributed immensely to the acceptable gender parity witnessed today. This is however contrary to a study done by UNESCO (2010) in Sub-Saharan Africa which stated that around 54\% of children out of school are girls. It further said that almost 12 million girls in Sub-Saharan Africa may never enroll. The United Nations has praised the move by the Kenyan Government to provide FPE as having the country "en-route" to reach the millennium development goals, enrolment and gender parity objectives at least in primary education (UNESCO, 2008). In remote rural areas like Lokichogio and Lodwar, the enrolment of girls had increased by nearly $40 \%$ (UNICEF, 2005).

Despite this praise by the UN, the country has not completely achieved gender parity. UNDP (2013), also concurs with these findings and says that the gross enrolment ratio for boys is still higher than that of girls, standing at $112.8 \%$ while for girls was $112.2 \%$ in 2009 . Though there has been a marked general growth in enrolment rates and close gender parity especially with the introduction of FPE, the regional and gender disparities are evident especially in the ASAL districts, pockets of poverty and the urban slums. The assumption that the poor will always benefit from such interventions such as FPE in Kenya may not be true if the channels of that subsidy are the limited public schools and there is a 'scramble' for them. Most studies therefore believe gender parity has not been achieved as far as enrolment is concerned. 


\section{Conclusion}

The enrolments were found to be generally on the rise. There is however gender parity in enrolment according to most respondents except for Nakuru North Sub-County where girls' enrolment is slightly below that of boys. In this study, students still got a chance to participate in class activities despite the increased enrolment. This is worth noting and contradicts earlier findings that there was little or no participation due to increased numbers. The study revealed said that dropout rates has declined though most studies have a contrary opinion for example UNESCO's 2010 Education for All Global Monitoring Report for Sub-Saharan Africa shows that while enrolment rates are rising, millions of children enter primary school only to dropout before completing a full primary cycle. The study depicts a significant increase in the transition rate, but the findings appear to contradict the views of the 2012 Economic Survey which shows that approximately 30 per cent of primary school pupils fail to transit to secondary school. The above findings, therefore confirm an increased rate of enrolment and retention rate. The researcher recommended for a blending in terms of funding- both Government, Private Sector and households.

\section{References:}

Ajetomobi, J. O. \& Ayanwale, A. B. (2005). Education Allocation, Unemployment, Economic Growth in Nigeria - 1979-2004. Retrieved from Sage on November 4th, 2010 from: http://www.saga.cornell-edu-/saga/educ conf. /Ajetomobi pfd.

Creswell, J. W (2009). Qualitative, Quantitative and Mixed Methods Approaches (3rd ed) Thousand Oaks, CA: Sage.

Creswell, J.W (2010). Understanding Research: A Consumer's Guide (1st Ed). Merrill Education, CA: Sage.

Creswell, J.W (2011). Designing and Conducting Mixed Methods Research (2ndEd) Thousand Oaks, CA: Sage.

Creswell,J.W(2002). Educational research: Planning conducting,and evaluating quantitative.

New Jersey: Upper Saddle River

Croft, A. (2002). "Singing under a tree": Does oral culture help lower primary teachers be learner-centered? International Journal of Educational Development, 22, 321-337.

DFID. (2010). Annual Report and Accounts Volume 1. London: Government of United Kingdom.

EFA Global Monitoring Reports (2004 by the United Nations Educational, and Cultural Organization 7, Place de Fontenoy, Graph print Paris. 
Elimu Yetu Coalition. (2004). Monitoring of the Free Primary Education and establishing the unit cost of primary education in Kenya. Nairobi: Elimu Yetu Coalition.

Government of Kenya. (2005). Kenya Education Sector Support Programme 2005-2010. Nairobi: MOEST;Science and Technology

Government of Kenya. (2009). Report of the task force on Free Primary Education. Nairobi: Jomo Kenyatta Foundation.

Government of Kenya. (2004). National Action Plan on Education for All 2003-2015. Nairobi: Government Press.

Government of Kenya (2006). Economic Survey: Government Printers: Nairobi. Government of Kenya (2007). Economic Survey: Nairobi: Government Printers: Nairobi.

Hanushek, E. A. (1979). Conceptual and empirical issues in the estimation of educational production functions. Journal of Human Resources, 14 (3), 351388.

Hanushek, E. A. (1995). Interpreting Recent Research on Schooling in Developing Countries.

World Bank Research Observer, 10 (2), 227-246.

Hanushek, E. A. (2007, January). Education Production Functions. United States of America:

Stanford University.

Heynemann, S.P. (2007). Volume 37 of Prospects:quarterly review of comparative education.

New York: UNESCO.

Jayachandaran, S. (2014). Incentives to teach badly: After school tutoring in developing countries. Journal of Development Economics Vol 108(1), 190205.

Kenya National Bureau of Statistics. (2014). Economic Survey Report. Nairobi: Government Press.

Kenya, P. (2008). The Kenya Free Primary Education Policy (FPE): An Assessment on the Impact and Sustainability of Free Primary Education in Migwani Division. CENDEP: Oxford Brookes University.

Krejcie, R. V., \& Morgan, D. W. (1970). Determining sample size for research activities. Educ psychol meas.

Kremer, M. (1993). The O-ring theory of economic development. The Quarterly Journal of Economics, 551-575.

MOEST :( 2005b) Education Sector Report, 2005. Nairobi: Government Press.

MOEST: Strategic Plan 2006-2011 Nairobi: Government Press

MOEST: (2008) Education for Sustainable Development. Implementation Strategy. Ministry of Education. 
MOEST: (2013). Educational Management Information Systems. Nairobi: Government Press MOEST: (2012). Kenya Facts and Figures. Nairobi: Kenya National Bureau Of Statistics. Nairobi:

Government Press.

Ministry of Education, Nakuru County Education Awards 2012. Nauru: Genvel Printers Ministry of Finance. (2007;2008). National Audit Report. Nairobi: Government Press. TSC County Director's Circular-(2012). Nakuru: TSC

Ngaroga, J. M. (1996). PTE Revision Education. Nairobi: East African Publishers.

Ogola, F. O. (2010). Free Education in Kenya's Public Primary Schools: Adressing the Challenges. Ethiopia: Organisation for Social Science Research in Eastern and Southern Africa.

Oketch, M., \& Somerset, A. (2010). Free Primary Education and after in Kenya: Enrolment, Impact, Quality, Effects and the transition to secondary school. London: University of Sussex, Centre for International Education.

Ondego, O. (2008, October 17). The Kenyan Universal Primary Education Mirage. Retrieved from Artmatters: http://artmatters.info/education/2008/10/the-kenyan-universal-primaryeducation-mirage/.

Patton, M. Q. (1990). Qualitative evaluation and research methods. New York: SAGE Publications, Inc.

Pritchett, L. \& Deon, F. (1999). What Education Production Functions Really Show: A Positive SACMEQ. (2011, October). Quality of Primary Schools Inputs in Mauritius. Retrieved from

SACMEQ: www.sacmeq.org

SACMEQ. (2011, June). Trends in Achievement Levels of Standard 6 Pupils in Kenya. Retrieved from www.sacmeq.org: www.sacmeq.org

Saleemi, N. A., \& Bogonko, J. (1997). Management Simplified . Principles and Practice. Nairobi: NA Saleemi Publishers.

Sawamura. D.N (2008). Universalizing primary education in Kenya: Is it beneficial and sustainable? Journal of Interntional Cooperation in Education, 11(3),103-118.

Sifuna, D. N. (2007). The Challenge of Increasing Access and Improving Quality: An analysis of Universal Primary Education Interventions in Kenya and Tanzania since the 1970s.

International Review of Education, 53(5-6), 687-699.

Sifuna, D. N., \& Sawamura, N. (2008). Universalizing primary education in Kenya: Is it beneficial and sustainable? Journal of International Cooperation, 11(3),103-118.

Somerset, A. (2010). Universalizing Primary Education in Kenya. Comparaative Education, 45(2), 233-250. 
The SACMEQ III in Kenya, (2005). A Study of the Conditions of Schooling and the Quality of Education. Retrieved on April15, 2011 from http://www.sacmeq.org/JEAPS

TSC-Annual Report 2007/2008. Nairobi: Government Press

TSC - Annual Report 2008/2009. Nairobi: Government Press

UNDP (2003). Human development report. New York: United Nations Development Programme.

UNESCO (2007). Education for All Global Monitoring Report 2008 Education for All by 2015: will we make it. Paris: Oxford University Press/

UNESCO (2002). Global Monitoring Unit. The 2002 Education for All Global Monitoring Units.

Paris: Oxford University Press.

UNESCO (2009). Education for All Global Monitoring Report, UNESCO (2004). EFA Global Monitoring Report 2005: Education for All- the Quality Imperative. Paris: Oxford University Press.

UNESCO (2010). Education (Moses Waithanji Ngware, 2009) n for All Global Monitoring Report. Retrieved January 3, 2010 from: www.efareport.unesco.org

UNESCO (2010) National Education Support Strategy (UNESS) for the Republic of Kenya.

Publishing Services Section. Nairobi-Kenya: UNON.

UNESCO (2005). Gender equality in education: Definitions and measurements. International Journal of Educational Development. 25(4) 395407.

UNESCO. (2008). Education For All, The Quality Imperative and the Problem of Pedagogy. Place de Fontenoy: UNESCO.

UNESCO. (2005). Challenges of Implementing Free Primary Education in Kenya :assessment report. Nairobi: Ministry of Science Education and Technology.

UNICEF (2005). Kenya Regional disparities threaten progress towards education for all. Retrieved January 3, 2010 from http:/ www.unicef.org./infoby county/Kenya newline.html

Wasanga, P., Ambia, G. \& Mwai, N. (2010). Assessment for the 21st Century: Impact of School Management Factors on Academic Achievement of Primary School Pupils in Kenya. Paper Presented During the 36th IAFA Annual Conference in Bangkok, Thailand.

Wax, E. (2003). Too Many Brains Pack Kenya's Schools. Washington Post Foreign Service, Pg. 24.www.sacmeq.org 